\title{
Informality and exclusion: evidence from matched employer-employee data for Lebanon and Syria
}

\author{
Mohamad Alloush ${ }^{*}$, Carole Chartouni, Roberta Gatti and Joana Silva
}

\author{
* Correspondence: \\ mmalloush@gmail.com \\ The World Bank, Washington, DC, \\ USA
}

\begin{abstract}
Informality, measured as the share of the employed who do not have access to social security, is high in Lebanon and the Syrian Arab Republic. This paper uses new data from the 2010 Lebanon and Syria matched employer-employee surveys, which include modules that directly test for ability (Raven's progressive matrices) and selfreported personality characteristics in addition to a detailed section on job quality. The analysis of differentials in earning, self-reported attitudes toward jobs, working conditions, and self-rated satisfaction across formal and informal jobs shows that, even after controlling for measured ability and personality traits, there is a significant formality premium. Moreover, in Lebanon, informal workers are significantly more likely than formal workers to want to change jobs. These findings suggest that much of the observed informality in these two countries might not be due to individual choice but more likely to exclusion from formal markets.

JEL codes: H53, H55, J23, J24, J31, J32, J42, J71, J81, K31, M51, 053
\end{abstract}

\section{Introduction}

Informality is best understood as a multifaceted phenomenon, influenced by the relationship that the state establishes with private agents through regulation, monitoring, and the provision of public services (see, for example, the discussion in Gatti et al. 2012). Countries in the Middle East and North Africa region are among the most informal economies in the world, producing an average of about one-third of their gross domestic products (GDP) and employing an average of about 67 percent of their labor forces informally (measured using the Schneider index ${ }^{1}$ and the share of the labor force without social security coverage, respectively) (Loayza and Wada 2010). Social insurance systems in these countries are based historically on the Bismarckian welfare state model, whereby pension, health, and disability benefits are linked to employment in the formal sector. In most countries, in return for their contributions, formal workers are entitled to generous benefit packages (Robalino 2005). Those outside the formal sector, in both urban and rural areas, traditionally have had limited or no access to formal risk management instruments or other government benefits.

The existing literature on informality traces its causes to different factors. In his seminal work, De Soto (1989) characterizes informality as the result of exclusion from formal markets. Instead, Perry et al. (2007) present evidence that informality in Latin American countries results mostly from the choices of individuals who rationally opt out of often inefficient and cumbersome formal markets. Other studies in Latin American

(C) 2013 Alloush et al.; licensee Springer. This is an Open Access article distributed under the terms of the Creative Commons Attribution License (http://creativecommons.org/licenses/by/2.0), which permits unrestricted use, distribution, and reproduction in any medium, provided the original work is properly cited. 
countries focus on the self-employed, finding that they choose informality to benefit from its flexibility and potentially higher earnings (Paulson and Townsend 2005; Fields 2005; Gunther and Launov 2011). Evidence on the Middle East and North Africa is more scant (see Gatti et al. 2012). However, with more than two-thirds of workers in some countries in the region without access to health or old-age insurance, understanding the determinants of informal employment is an important objective in the labor literature as well as for policy making in the region (Arias and Khamis 2008).

Defining and measuring informality are not a simple tasks. De Soto (1989) broadly defines informality as the collective realm of firms, workers, and activities that operate outside of the regulatory framework. Informality can be studied through three main lenses: a firm-based perspective, an employment perspective (at the individual level), and a fiscal perspective (untaxed activities) (Gatti et al. 2012; Gasparini and Tornarolli 2009). In this paper, we focus on informality at the individual level whereby those employees who are not registered through their firms in the national social insurance schemes (the National Social Security Fund in Lebanon and the General Establishment for Social Insurance in Syria) are considered informal (as in Maloney 2004; Perry et al. 2007; Angel-Urdinola et al. 2009). According to this definition, employees of registered firms may well be informal if the firms do not register them in the national government's social insurance scheme.

Estimating the formality premium presents some challenges. Even after controlling for education and experience, the wage differences between formal and informal work can reflect significant, usually unobserved, factors: compensating differentials for those who prefer flexible hours and schedule, fewer working hours, the value of training, and the actual value of social security benefits given (for example, the quality of the services to which the benefits give access) (see, for example, Maloney 1999, 2004; Marcoullier et al. 1997). At the same time, selection into formal or informal jobs might be driven by unobservable skills and ability, which in turn might also affect earnings. Thus, for individuals with low (unobserved) skills who fall into informal employment and earn little because of their limited ability, their lower wages relative to those of formal workers might be erroneously attributed to informality rather than low productivity. In spite of the central role played by informal labor in developing countries, little research has been conducted on the estimation of the formality premium controlling for these variables. This is often due to data limitations, since household surveys and labor force surveys do not collect information on skills beyond educational achievement and years of work experience.

This paper explores the determinants of informality and the informal-formal wage gap in Lebanon and Syria. Given its focus on workers' vulnerability, the paper defines informal workers as those who are not registered in the national social security scheme. Using this definition, it characterizes differences in labor market outcomes between formal and informal workers along a rich set of individual and firm characteristics (including age, education, firm size, location, and sector). More importantly, it brings a new dimension to the existing literature by explicitly accounting for direct measures of cognitive ability and socioemotional personality traits, which are usually not observed. It does so using matched employer-employee data collected by the World Bank in Lebanon and Syria that include individual results from nonverbal cognitive tests (measuring workers' logical and analytical skills) as well as self-assessed personality 
tests. We find that cognitive and noncognitive measures are, overall, weakly associated with the probability of being informal and that the wage gap between formal and informal workers persists even once these proxies for ability are accounted for.

The paper also exploits a wealth of information on quality of employment and selfreported workers' preferences to inform the debate on whether informality in the Middle East and North Africa results from exclusion or from choice to opt out of social security coverage. To this end, the paper explores other differences across formal and informal jobs, such as job duration, benefits, and job satisfaction. In contrast with evidence for Mexico and other Latin American countries, this paper finds that informal jobs in Lebanon and Syria are associated with worse benefits and lower satisfaction than comparable formal jobs ${ }^{2}$. Finally, the paper discusses some conclusions and policy recommendations from the analysis.

\section{Labor markets in Lebanon and Syria}

In Lebanon, the overall labor force participation in 2010 was 46 percent, up from 44 percent in 2004. Female labor force participation was low by international standards, at 20 percent, but has been steadily increasing over time. Relative to countries with similar income levels, the Lebanese labor force is well educated, with over a third of individuals having completed tertiary education (Robalino et al. 2012). The country registers high levels of skilled-labor out-migration and a relatively large inflow of low-skilled workers from other Arab countries (Kasparian 2009; Robalino et al. 2012).

In 2010, unemployment was relatively high in Lebanon (around 11 percent). Overall in the country, unemployment rates decreased with age but increased with educational attainment. However, unemployment duration was significantly higher for individuals with lower education. Moreover, 40 percent of those employed in the private sector were not registered in the National Social Security Fund (NSSF) and thus, by this paper's definition, were informal ${ }^{3}$. Patterns of informality vary considerable by age, being higher among the youth (particularly among those 15-24 years old) and decreasing rapidly when individuals reach $40-45$ years of age (Gatti et al. 2012). It is estimated that 36 percent of the labor force is self-employed (Robalino et al. 2012) .

In 2009 the Syrian labor market faced many challenges. First, the labor force participation rate was relatively low by international standards ( 52 percent), which was mainly associated with the low participation of women in the labor force (14 percent). Furthermore, the unemployment rate was 8.4 percent and was heavily concentrated among first-time job seekers, with youth unemployment reaching 20 percent in $2009^{5}$. Moreover, 72 percent of the labor force was not covered by the national social insurance scheme and, according to the definition used in our analysis, are considered informal ${ }^{6}$.

\section{The data}

The datasets used in this paper are from the World Bank's 2010 matched employeremployee surveys for Lebanon and Syria. The 2010 Syria employer-employee dataset contains information on 961 private sector workers employed in 116 firms in the manufacturing and services sectors. The 2010 Lebanon employer-employee survey surveyed a total of 1,841 labor force participants ${ }^{7}$ of which 764 were employees in the private sector. These surveys were implemented in two different ways. In Syria, the World Bank Enterprise Survey ${ }^{8}$, nationally representative of the private sector in 
the country, was first fielded in 2009. Then in 2010, employee data collection complemented the firm survey by interviewing a random sample of workers in these firms. In Lebanon, the World Bank selected a nationally representative sample of households whose working members responded to an extensive labor force module. Information was collected from workers on each firm (including contact information, size, location, and industry). Based on this information, a nationally representative sample of firms was then selected for interviews to collect additional firm-level information. The distinct features of the two surveys enable a deeper and complementary understanding of informality.

These datasets include not only basic data on the socioeconomic characteristics of workers but also data on wages (starting and current levels, including bonuses), job benefits, working conditions, and variables indicating the individuals' overall job satisfaction, which allow us to compare formal and informal workers across these dimensions. Moreover, they contain information on workers' skills assessment, including cognitive and noncognitive tests that we used to proxy individual ability and personality traits, allowing the analysis to compute the formality premium controlling for such traits.

Finally, the two surveys provide data on whether each individual is registered in social security, which were used to define informality in this paper. A worker is classified as informal if he or she is an employee and works without being registered in the national social insurance scheme. Public employees were not considered in the analysis because they are not included in the sample in either country. Hence all comparisons between countries refer to private sector employees only. For Lebanon, a separate sample of self-employed was available, which we used to compare self-employed individuals with formal and informal employees. For Syria, this comparison was not possible because data on the self-employed were not available.

\section{Ability, personality traits, and informality}

Traditionally, studies have focused on measuring skills through educational attainment and experience, without measuring ability directly. Ability might affect labor market outcomes, including earnings. The ability bias has been discussed in the literature, and Griliches (1977) provides one of the earliest attempts to correct for unmeasured ability in the context of estimating returns to schooling. Although ability is not observable, cognitive and noncognitive tests can be good proxies. An individual's skill set can be defined as a combination of cognitive, socioemotional, and technical skills. In turn, given that human capital is multidimensional, both cognitive and socioemotional skills can serve as good predictors of economic outcomes such as income and wealth (Bowles et al. 2001; Hansen et al. 2004; Heckman et al. 2006; Green and Riddell 2003).

To measure cognitive skills of the labor force, the Lebanon and Syria surveys use the "Raven's Progressive Matrices," a nonverbal, multiple-choice test in which individuals have to identify the logical missing piece of a particular pattern of matrices. In these tests, respondents have five minutes to answer as many of the 12 questions as they can. The patterns in the questions become progressively more difficult, requiring greater cognitive capacity. This test is independent of language, reading, or writing skills; it focuses on measuring observation skills, analytical ability, and intellectual capacity (Raven 1989; Jensen 1998). A score (in increments of 1 out of 12) is calculated for each respondent based on the number of correct answers completed in the allocated time. 
Results on mean scores of formal and informal workers in Lebanon and Syria are reported in Table 1. They indicate that formal employees in Lebanon, on average, score higher than informal employees and that this difference decreases as educational level increases. In contrast, the reverse is true in Syria, where informal workers have higher average cognitive scores and the observed difference increases with education. Both countries show decreasing scores with age.

The noncognitive assessments consist of a list of statements describing personal behaviors and characteristics corresponding to the five core dimensions of personality used in the psychology literature to classify human personality (referred to as the "Big Five"):

- Conscientiousness: tendency to be organized, responsible, and hardworking

- Emotional stability: tendency to be predictable and consistent in emotional reactions

- Agreeableness: tendency to act in a cooperative and unselfish manner

- Extraversion: tendency to orient one's energies toward the outer world of people and things

- Openness to experience: tendency to be open to new cultural or intellectual experiences

These traits have been shown to be relevant across cultures and considered to be relatively stable throughout one's lifetime (John and Srivastava 1999). Studies have also shown that personality characteristics and socioemotional skills are important predictors of economic outcomes in an individual's lifetime (Borghans et al. 2008; Paunonen 2003; Heckman and Rubinstein 2001). The noncognitive test used in the Syria and Lebanon surveys-an adaption of the Goldberg test (Goldberg 1993)—asks respondents

Table 1 Cognitive score means of formal and informal workers by education, gender, and age group

\begin{tabular}{|c|c|c|c|c|c|c|}
\hline & \multicolumn{3}{|l|}{ Lebanon } & \multicolumn{3}{|l|}{ Syria } \\
\hline & Average & Formal & Informal & Average & Formal & Informal \\
\hline Overall & 5.13 & 5.54 & 4.85 & 4.56 & 4.44 & 4.86 \\
\hline \multicolumn{7}{|c|}{ Education level } \\
\hline No formal ed & 3.37 & 3.53 & 3.22 & 2.57 & 2.48 & 2.68 \\
\hline Primary & 3.97 & 4.17 & 3.79 & 3.80 & 3.75 & 3.92 \\
\hline Secondary & 5.13 & 5.26 & 4.89 & 4.62 & 4.46 & 5.05 \\
\hline Tertiary & 6.09 & 6.12 & 6.10 & 5.76 & 5.50 & 6.50 \\
\hline \multicolumn{7}{|l|}{ Gender } \\
\hline Male & 5.17 & 5.41 & 4.76 & 4.58 & 4.49 & 4.83 \\
\hline Female & 5.06 & 5.34 & 4.64 & 4.48 & 4.22 & 4.93 \\
\hline \multicolumn{7}{|l|}{ Age group } \\
\hline $15-24$ & 5.24 & 5.82 & 4.76 & 4.48 & 4.41 & 4.55 \\
\hline $25-34$ & 5.71 & 5.78 & 5.56 & 4.84 & 4.68 & 5.24 \\
\hline $35-44$ & 4.87 & 5.15 & 4.32 & 4.41 & 4.35 & 4.64 \\
\hline $45-54$ & 4.94 & 5.08 & 4.65 & 4.24 & 4.20 & 4.52 \\
\hline $54+$ & 2.81 & 3.45 & 1.80 & 4.05 & 3.68 & 5.41 \\
\hline
\end{tabular}

Note: Cognitive test scores are based on the Raven Progressive Matrices (Raven 1989). 
to rank on a scale of 1 to 7 the applicability of 15 traits or behaviors, each of which correspond to one of the "Big Five." With this information, a score for each of the "Big Five" traits is calculated. In our regression analysis, we capture noncognitive skills with a dummy taking the value of one if an individual is above the average self-rated score for a particular trait ${ }^{9}$.

\section{Empirical strategy and results}

\subsection{Determinants of informality}

We first estimate the determinants of informality in Lebanon and Syria. Table 2 depicts the probit regression outcomes for probability of being informal. In Lebanon, the coefficients on education and age are negative and significant. Older or more educated individuals are less likely to be informal. Firm size is significant in predicting informality, whereby working at a smaller firm significantly increases the chances of being informal. Among personal traits, openness to experience is positive and significant when it comes to predicting informality, whereas extraversion is significant yet makes an individual less likely to be employed informally. However, the results show that cognitive ability plays no significant role in the equation. Results are fairly similar for the Syria sample ${ }^{10}$. As in Lebanon, cognitive ability is not a significant predictor of informality in Syria. Moreover, an individual is more likely to informal if he or she is employed at a small firm. Age is also significant as younger individuals are more likely to be employed in informal jobs.

\subsection{Formality premium}

This section estimates the earnings gap between formal and informal employment, taking different variables into account, including ability and personal characteristics. Ceteris paribus, one assumes that, when given the choice, a person would prefer the job with higher earnings. Considering income as a proxy for individual utility and embedded in the principle of revealed preferences (Nguyen et al. 2013), an individual would not choose to be employed informally if the overall earnings are significantly lower in the informal sector. In other words, for salaried workers, a significant earnings gap between a formal and an informal job would lead them to prefer the formal job unless more benefits or better working conditions were associated with the informal job.

When considering unconditional earnings, formal workers have higher average hourly earnings than informal workers (see Table 3). In Lebanon, informal workers earn 36 percent less per hour than their formal counterparts. An earnings gap exists across nearly all educational, gender, and age groups. In addition, an earnings gap is observed across different industries ${ }^{11}$ and firm sizes as well as regions of the country. In Syria, informal employees earn 19 percent less per hour than their formal counterparts, and an earnings gap exists across nearly all educational, ability, and age groups as well as sectors, firm sizes, and regions ${ }^{12}$.

We use kernel density plots of hourly wages for the formal and informal sectors to further illustrate this result (see Figure 1). These density plots show that the estimated probability density function (pdf) of wages in the formal sector is to the right of the pdf of wages in the informal sector, suggesting the existence of a formality premium throughout the wage distribution. 
Table 2 Determinants of informality regressions (probit regressions, marginal effects reported)

\begin{tabular}{|c|c|c|c|c|}
\hline \multirow[b]{2}{*}{ Dependent variable informal } & \multicolumn{2}{|l|}{ Lebanon } & \multicolumn{2}{|l|}{ Syria } \\
\hline & (1) & $(2)$ & (3) & (4) \\
\hline \multirow[t]{2}{*}{ Female } & -0.0123 & -0.0162 & 0.0573 & 0.0489 \\
\hline & $(0.0584)$ & $(0.0610)$ & $(0.0584)$ & $(0.0609)$ \\
\hline \multirow[t]{2}{*}{ Years of education } & $-0.0172^{* * *}$ & $-0.0201^{* * *}$ & -0.00542 & -0.00527 \\
\hline & $(0.0054)$ & $(0.0060)$ & $(0.00440)$ & $(0.00490)$ \\
\hline \multirow[t]{2}{*}{ Age } & $-0.0545^{* * *}$ & $-0.0614^{* * *}$ & $-0.0565^{* * *}$ & $-0.0562^{* * *}$ \\
\hline & $(0.0153)$ & $(0.0161)$ & $(0.0123)$ & $(0.0126)$ \\
\hline \multirow[t]{2}{*}{$\mathrm{Age}^{2}$} & $0.0006^{* * *}$ & $0.0007^{* * *}$ & $0.000640^{* * *}$ & $0.000634^{* * *}$ \\
\hline & $(0.0002)$ & $(0.0002)$ & $(0.000160)$ & $(0.000163)$ \\
\hline \multirow[t]{2}{*}{ Firm size < 5 (base 10-49) } & $0.5321^{* * *}$ & $0.5303^{* * *}$ & $0.297^{* * *}$ & $0.308^{* * *}$ \\
\hline & $(0.0614)$ & $(0.0653)$ & $(0.0827)$ & $(0.0803)$ \\
\hline \multirow[t]{2}{*}{ Firm size 5-9 } & $0.2089^{* *}$ & $0.2108^{* *}$ & $0.268^{* * *}$ & $0.279^{* * *}$ \\
\hline & $(0.0832)$ & $(0.0853)$ & $(0.0860)$ & $(0.0883)$ \\
\hline \multirow[t]{2}{*}{ Firm size $>50$} & $-0.1921^{* * *}$ & $-0.2358^{* * *}$ & $-0.285^{* * *}$ & $-0.273^{* * *}$ \\
\hline & $(0.0576)$ & $(0.0583)$ & $(0.0730)$ & $(0.0746)$ \\
\hline \multirow[t]{2}{*}{ Cognitive score quintile 2} & & 0.1063 & & 0.0408 \\
\hline & & $(0.0823)$ & & $(0.0521)$ \\
\hline \multirow[t]{2}{*}{ Cognitive score quintile 3} & & 0.0667 & & 0.00539 \\
\hline & & $(0.0864)$ & & $(0.0515)$ \\
\hline \multirow[t]{2}{*}{ Cognitive score quintile 4} & & 0.0051 & & 0.0116 \\
\hline & & $(0.0863)$ & & $(0.0743)$ \\
\hline \multirow[t]{2}{*}{ Cognitive score quintile 5} & & 0.1107 & & 0.0258 \\
\hline & & $(0.0939)$ & & $(0.0879)$ \\
\hline \multirow[t]{2}{*}{ Open to experience } & & $0.1329^{* *}$ & & -0.0129 \\
\hline & & $(0.0572)$ & & $(0.0389)$ \\
\hline \multirow[t]{2}{*}{ Conscientious } & & 0.0166 & & -0.00476 \\
\hline & & $(0.0583)$ & & $(0.0611)$ \\
\hline \multirow[t]{2}{*}{ Extrovert } & & $-0.1509^{* * *}$ & & -0.0360 \\
\hline & & $(0.0549)$ & & $(0.0409)$ \\
\hline \multirow[t]{2}{*}{ Agreeable } & & -0.0268 & & 0.0406 \\
\hline & & $(0.0584)$ & & $(0.0450)$ \\
\hline \multirow[t]{2}{*}{ Emotionally stable } & & -0.0558 & & -0.0322 \\
\hline & & $(0.0561)$ & & $(0.0464)$ \\
\hline Observations & 502 & 490 & 928 & 928 \\
\hline Pseudo- $R^{2}$ & 0.299 & 0.326 & 0.173 & 0.173 \\
\hline
\end{tabular}

Note: Robust standard errors in parentheses. ${ }^{* * *} \mathrm{p}<0.01,{ }^{* *} \mathrm{p}<0.05,{ }^{*} \mathrm{p}<0.1$. All regressions include industry and region dummies. Regions in Lebanon were Beirut, Mount Lebanon, North Lebanon, Bekaa, South Lebanon, and Nabatieh. Regions in Syria were Damascus, Aleppo, Hama, Homs, and Latakia. In Lebanon, the industries include agriculture, construction, education, wholesale, transport, finance, information and communications, and health. In Syria, the industries include services and manufacturing.

Finally, we estimate the formality premium using different specifications of the Mincerian-type regressions ${ }^{13}$. The dependent variable is the log hourly wage, taking yearly bonuses into account and dividing by the estimated number of hours worked. Results from the baseline regression (which includes as explanatory variables gender, 
Table 3 Average hourly wages in Lebanon and Syria for salaried workers (USD)

\begin{tabular}{|c|c|c|c|c|c|c|c|c|}
\hline & \multicolumn{4}{|c|}{ Lebanon } & \multicolumn{4}{|l|}{ Syria } \\
\hline & Overall & Formal & Informal & \% Difference & Overall & Formal & Informal & \% Difference \\
\hline Total & 3.98 & 4.67 & 3 & $-35.80 \%$ & 2.12 & 2.23 & 1.81 & $-19.10 \%$ \\
\hline \multicolumn{9}{|l|}{$\begin{array}{l}\text { Educational } \\
\text { attainment }\end{array}$} \\
\hline No formal education & 2.64 & 2.93 & 1.89 & $-35.50 \%$ & 1.32 & 1.41 & 1.17 & $-17.00 \%$ \\
\hline Primary & 3.68 & 3.95 & 2.48 & $-37.20 \%$ & 1.69 & 1.82 & 1.34 & $-26.50 \%$ \\
\hline Secondary & 3.95 & 3.87 & 2.92 & $-24.30 \%$ & 1.88 & 1.95 & 1.69 & $-13.40 \%$ \\
\hline Tertiary & 5.24 & 5.68 & 4.03 & $-29.00 \%$ & 2.87 & 2.97 & 2.58 & $-13.20 \%$ \\
\hline \multicolumn{9}{|l|}{ Ability proxy } \\
\hline $\begin{array}{l}\text { Cognitive score } \\
\text { quintile } 1\end{array}$ & 3.53 & 3.78 & 3.09 & $-18.20 \%$ & 1.75 & 1.86 & 1.37 & $-26.30 \%$ \\
\hline $\begin{array}{l}\text { Cognitive score } \\
\text { quintile } 2\end{array}$ & 3.71 & 4.27 & 2.61 & $-38.90 \%$ & 1.73 & 1.78 & 1.6 & $-9.90 \%$ \\
\hline $\begin{array}{l}\text { Cognitive score } \\
\text { quintile } 3\end{array}$ & 4.02 & 4.66 & 2.79 & $-40.20 \%$ & 2.05 & 2.07 & 1.98 & $-4.50 \%$ \\
\hline $\begin{array}{l}\text { Cognitive score } \\
\text { quintile } 4\end{array}$ & 4.79 & 5.55 & 2.86 & $-48.40 \%$ & 2.53 & 2.72 & 1.92 & $-29.40 \%$ \\
\hline $\begin{array}{l}\text { Cognitive score } \\
\text { quintile } 5\end{array}$ & 4.64 & 5.34 & 3.41 & $-36.10 \%$ & 2.67 & 3.14 & 2.02 & $-35.50 \%$ \\
\hline \multicolumn{9}{|l|}{ Gender } \\
\hline Male & 4.08 & 4.67 & 3.16 & $-32.50 \%$ & 2.2 & 2.3 & 1.91 & $-17.10 \%$ \\
\hline Female & 3.74 & 4.68 & 2.67 & $-42.80 \%$ & 1.77 & 1.91 & 1.52 & $-20.20 \%$ \\
\hline \multicolumn{9}{|l|}{ Age group } \\
\hline $15-24$ & 3.39 & 4.16 & 2.72 & $-34.60 \%$ & 1.54 & 1.58 & 1.5 & $-4.90 \%$ \\
\hline $25-34$ & 4.11 & 4.67 & 3.21 & $-31.20 \%$ & 1.94 & 2.02 & 1.73 & $-14.30 \%$ \\
\hline $35-44$ & 4.22 & 5.28 & 2.54 & $-51.90 \%$ & 2.32 & 2.41 & 1.96 & $-18.50 \%$ \\
\hline $45-54$ & 4.07 & 4.49 & 2.21 & $-50.80 \%$ & 3 & 3.04 & 2.72 & $-10.50 \%$ \\
\hline $54+$ & 3.89 & 4.03 & 5.29 & $31.40 \%$ & 2.47 & 2.46 & 2.49 & $1.00 \%$ \\
\hline \multicolumn{9}{|l|}{ Firm size } \\
\hline$<5$ & 2.44 & 4.07 & 2.14 & $-47.40 \%$ & 2.18 & 3.12 & 1.84 & $-41.20 \%$ \\
\hline $5-9$ & 3.87 & 4.76 & 2.95 & $-38.10 \%$ & 1.81 & 1.9 & 1.77 & $-7.00 \%$ \\
\hline $10-49$ & 4.53 & 4.74 & 3.89 & $-18.00 \%$ & 2.13 & 2.27 & 1.97 & $-13.40 \%$ \\
\hline $50+$ & 4.64 & 4.73 & 4.36 & $-7.80 \%$ & 2.13 & 2.23 & 1.7 & $-23.40 \%$ \\
\hline \multicolumn{9}{|l|}{ Economic sector } \\
\hline Agriculture & 3.13 & 4.43 & 2.58 & $-41.70 \%$ & n.a & n.a & n.a & n.a \\
\hline Manufacturing & 3.88 & 4.26 & 2.4 & $-43.60 \%$ & 2.07 & 2.16 & 1.82 & $-18.93 \%$ \\
\hline Services & 4.09 & 4.78 & 3.13 & $-34.50 \%$ & 2.3 & 2.54 & 1.77 & $-43.07 \%$ \\
\hline
\end{tabular}

Note: Exchange rates considered were $1 \mathrm{USD}=1,507 \mathrm{LL}$ (Lebanon) and 1USD $=48.2 \mathrm{SL}$ (Syria).

age, age squared, years of education, and a dummy variable equal to one if the worker holds a formal job) are depicted in regressions (1) and (3) in Table 4 for Lebanon and Syria, respectively. These regressions also control for firm size, region, and industry. Regressions (2) and (4) add cognitive test score quintiles and the personality trait dummy variables.

The estimated formality premium in the baseline regression is 23 percent and 12 percent for Lebanon and Syria, respectively. It is important to control for firm characteristics such as firm size and industry because these variables can potentially make an 


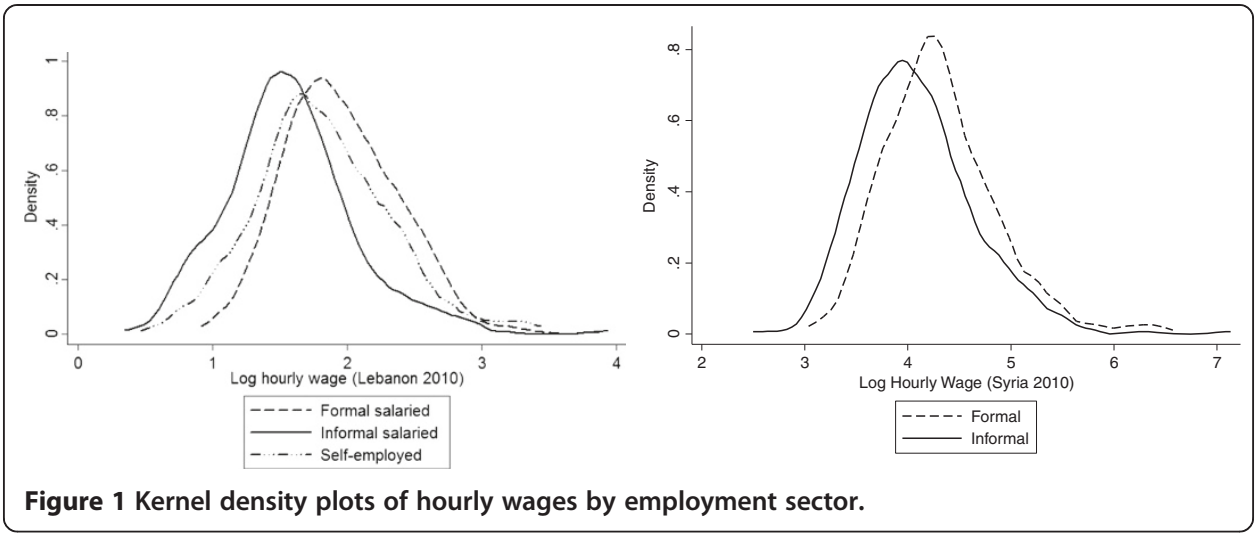

important difference in earnings. These firm characteristics could be considered proxies for productivity, which in turn could determine the wages that individuals receive. Omitting this variable from an analysis of wage differentials could lead one to spuriously attribute the formality premium to informal employment when it might instead reflect firm characteristics. However, the results in Table 4 show that the earnings gap between formal and informal workers persists even when firm size, region, and industry are taken into account ${ }^{14}$.

Because assignment to the informal sector is not random, it is important to control in some way for individual ability or skills to ensure that the attribution of the formality premium does not instead reflect other usually unobservable factors. To overcome this limitation in the interpretation of the estimation, the results of direct cognitive and noncognitive tests are included in the regressions. When these are explicitly accounted for, the formality premium is virtually unchanged: formal employment is associated with a 22 percent premium in Lebanon and a 12 percent premium in Syria ${ }^{15}$. This shows that, in Lebanon and Syria, it is unlikely that the formality premium can be explained solely by workers' ability and socioemotional characteristics.

Nonetheless, ability and some personality traits do somehow influence earnings within the formal sector, albeit more in Lebanon than in Syria. When separate regressions are run for formal and informal workers (see Table 5), cognitive score measures have a significant effect on formal worker earnings in Lebanon. Formal workers with cognitive scores in the fourth and fifth quintiles earn 20-25 percent more than those who scored in the first quintile. On the other hand, the ability of informal workers in Lebanon does not significantly influence their earnings. Similarly in Syria, cognitive scores do not seem to influence the wage determination in the informal sector; however, formal workers with cognitive scores in the fifth quintile earn 24 percent more than formal workers who scored in the first quintile ${ }^{16}$.

\subsection{Quality of jobs}

When it comes to the quality of jobs, the evidence suggests that formal workers in general have better-quality employment in terms of benefits and stability (see Table 6). Formal workers in both Lebanon and Syria are more likely than informal workers to have written contracts and are also more likely (in Lebanon) to be able to choose when to work overtime and to get paid for it $^{17}$ in addition to having overall higher earnings. Around 64 percent and 77 percent of formal workers in Lebanon and Syria, respectively, 
Table 4 Regressions for estimating the formality premium

\begin{tabular}{|c|c|c|c|c|}
\hline \multirow[b]{2}{*}{ Dependent variable: log hourly wage } & \multicolumn{2}{|l|}{ Lebanon } & \multicolumn{2}{|l|}{ Syria } \\
\hline & (1) & (2) & (3) & (4) \\
\hline \multirow[t]{2}{*}{ Formal } & $0.2340^{* * *}$ & $0.2159^{* * *}$ & $0.123^{* * *}$ & $0.119^{* * *}$ \\
\hline & $(0.0492)$ & $(0.0523)$ & $(0.0443)$ & $(0.0448)$ \\
\hline \multirow[t]{2}{*}{ Female } & $-0.0966^{* *}$ & $-0.0872^{* *}$ & $-0.137^{* * *}$ & $-0.122^{* * *}$ \\
\hline & $(0.0442)$ & $(0.0440)$ & $(0.0453)$ & $(0.0442)$ \\
\hline \multirow[t]{2}{*}{ Years of education } & $0.0203^{* * *}$ & $0.0169^{* * *}$ & $0.0418^{* * *}$ & $0.0334^{* * *}$ \\
\hline & $(0.0045)$ & $(0.0048)$ & $(0.00429)$ & $(0.00424)$ \\
\hline \multirow[t]{2}{*}{ Age } & 0.0135 & 0.0121 & $0.0460^{* * *}$ & $0.0465^{* * *}$ \\
\hline & $(0.0136)$ & $(0.0137)$ & $(0.0126)$ & $(0.0121)$ \\
\hline \multirow[t]{2}{*}{$\mathrm{Age}^{2}$} & -0.0001 & -0.0001 & $-0.000468^{* * *}$ & $-0.000470^{* * *}$ \\
\hline & $(0.0002)$ & $(0.0002)$ & $(0.000168)$ & $(0.000159)$ \\
\hline \multirow[t]{2}{*}{ Firm size < 5 (base 10-49) } & $-0.1615^{* *}$ & $-0.1591^{* *}$ & 0.0489 & 0.000480 \\
\hline & $(0.0657)$ & $(0.0671)$ & $(0.0865)$ & $(0.0864)$ \\
\hline \multirow[t]{2}{*}{ Firm size 5-9 } & -0.0123 & -0.0398 & -0.0747 & -0.0460 \\
\hline & $(0.0617)$ & $(0.0670)$ & $(0.0840)$ & $(0.0843)$ \\
\hline \multirow[t]{2}{*}{ Firm size $>50$} & 0.0092 & -0.0201 & -0.0740 & -0.0683 \\
\hline & $(0.0534)$ & $(0.0530)$ & $(0.0688)$ & $(0.0667)$ \\
\hline \multirow[t]{2}{*}{ Cognitive score quintile 2} & & 0.0409 & & -0.00731 \\
\hline & & $(0.0605)$ & & $(0.0520)$ \\
\hline \multirow[t]{2}{*}{ Cognitive score quintile 3} & & $0.1341^{* *}$ & & 0.0397 \\
\hline & & $(0.0666)$ & & $(0.0553)$ \\
\hline \multirow[t]{2}{*}{ Cognitive score quintile 4} & & $0.1897^{* * *}$ & & 0.0903 \\
\hline & & $(0.0675)$ & & $(0.0651)$ \\
\hline \multirow[t]{2}{*}{ Cognitive score quintile 5} & & $0.1424^{* *}$ & & $0.229^{* * *}$ \\
\hline & & $(0.0713)$ & & $(0.0760)$ \\
\hline \multirow[t]{2}{*}{ Open to experience } & & 0.0185 & & $0.0882^{* * *}$ \\
\hline & & $(0.0430)$ & & $(0.0311)$ \\
\hline \multirow[t]{2}{*}{ Conscientious } & & 0.0073 & & -0.00841 \\
\hline & & $(0.0431)$ & & $(0.0446)$ \\
\hline \multirow[t]{2}{*}{ Extrovert } & & $0.0732^{*}$ & & -0.0324 \\
\hline & & $(0.0433)$ & & $(0.0383)$ \\
\hline \multirow[t]{2}{*}{ Agreeable } & & $-0.1089^{* * *}$ & & $-0.168^{* * *}$ \\
\hline & & $(0.0415)$ & & $(0.0382)$ \\
\hline \multirow[t]{2}{*}{ Emotionally stable } & & $0.0725^{*}$ & & -0.0361 \\
\hline & & $(0.0418)$ & & $(0.0390)$ \\
\hline \multirow[t]{2}{*}{ Constant } & $1.3230^{* * *}$ & $1.2106^{* * *}$ & & $3.082^{* * *}$ \\
\hline & $(0.2542)$ & $(0.2642)$ & & $(0.243)$ \\
\hline Observations & 503 & 491 & & 928 \\
\hline R-squared & 0.3817 & 0.4351 & & 0.300 \\
\hline
\end{tabular}

Note: Robust standard errors in parentheses. ${ }^{* *} \mathrm{p}<0.01,{ }^{* *} \mathrm{p}<0.05,{ }^{*} \mathrm{p}<0.1$. Regression (2) for Lebanon and (4) for Syria control for industry and region dummies.

have written contracts with their firms; those percentages significantly shrink, to 18.4 percent and 26.7 percent, for informal workers. These differences hold even when we control for educational level, gender, age, and firm size. We also add cognitive and 
Table 5 Separate regressions for formal and informal employees

\begin{tabular}{|c|c|c|c|c|}
\hline \multirow[b]{2}{*}{ Dependent variable: log hourly wage } & \multicolumn{2}{|l|}{ Lebanon } & \multicolumn{2}{|l|}{ Syria } \\
\hline & $\begin{array}{l}\text { Formal } \\
\text { (1) }\end{array}$ & $\begin{array}{l}\text { Informal } \\
\text { (2) }\end{array}$ & $\begin{array}{l}\text { Formal } \\
\text { (3) }\end{array}$ & $\begin{array}{l}\text { Informal } \\
\text { (4) }\end{array}$ \\
\hline \multirow[t]{2}{*}{ Female } & -0.0263 & -0.1113 & $-0.116^{*}$ & $-0.165^{* * *}$ \\
\hline & $(0.0537)$ & $(0.0680)$ & $(0.0622)$ & $(0.0599)$ \\
\hline \multirow[t]{2}{*}{ Years of education } & $0.0162^{* * *}$ & $0.0216^{* * *}$ & $0.0272^{* * *}$ & $0.0427^{* * *}$ \\
\hline & $(0.0059)$ & $(0.0080)$ & $(0.00566)$ & $(0.00629)$ \\
\hline \multirow[t]{2}{*}{ Age } & $0.0398^{* * *}$ & -0.0273 & $0.0346^{* *}$ & $0.0599^{* * *}$ \\
\hline & $(0.0151)$ & $(0.0244)$ & $(0.0158)$ & $(0.0175)$ \\
\hline \multirow[t]{2}{*}{$\mathrm{Age}^{2}$} & $-0.0004^{* *}$ & 0.0004 & -0.000276 & $-0.000714^{* * *}$ \\
\hline & $(0.0002)$ & $(0.0003)$ & $(0.000203)$ & $(0.000237)$ \\
\hline \multirow[t]{2}{*}{ Firm size <5 (base 10-49) } & 0.0005 & -0.1273 & 0.151 & -0.0102 \\
\hline & $(0.1171)$ & $(0.0831)$ & $(0.170)$ & $(0.0791)$ \\
\hline \multirow[t]{2}{*}{ Firm size 5-9 } & -0.1128 & 0.0630 & -0.0487 & -0.0205 \\
\hline & $(0.0966)$ & $(0.1181)$ & $(0.144)$ & $(0.0869)$ \\
\hline \multirow[t]{2}{*}{ Firm size $>50$} & -0.0687 & 0.0620 & -0.0375 & -0.0733 \\
\hline & $(0.0547)$ & $(0.1235)$ & $(0.0775)$ & $(0.0847)$ \\
\hline \multirow[t]{2}{*}{ Cognitive score quintile 2} & 0.0555 & -0.0350 & -0.00565 & -0.0397 \\
\hline & $(0.0777)$ & $(0.0976)$ & $(0.0706)$ & $(0.0760)$ \\
\hline \multirow[t]{2}{*}{ Cognitive score quintile 3} & $0.1395^{*}$ & 0.1285 & -0.0175 & 0.0925 \\
\hline & $(0.0756)$ & $(0.1057)$ & $(0.0726)$ & $(0.0680)$ \\
\hline \multirow[t]{2}{*}{ Cognitive score quintile 4} & $0.2555^{* * *}$ & 0.1268 & 0.103 & 0.0551 \\
\hline & $(0.0784)$ & $(0.1080)$ & $(0.0873)$ & $(0.0885)$ \\
\hline \multirow[t]{2}{*}{ Cognitive score quintile 5} & $0.1987^{* *}$ & 0.0592 & $0.244^{* *}$ & 0.124 \\
\hline & $(0.0861)$ & $(0.1175)$ & $(0.109)$ & $(0.108)$ \\
\hline \multirow[t]{2}{*}{ Open to experience } & 0.0116 & 0.0600 & $0.0958^{* *}$ & 0.0804 \\
\hline & $(0.0534)$ & $(0.0634)$ & $(0.0365)$ & $(0.0525)$ \\
\hline \multirow[t]{2}{*}{ Conscientious } & 0.0776 & $-0.1202^{*}$ & -0.0461 & 0.000522 \\
\hline & $(0.0555)$ & $(0.0673)$ & $(0.0590)$ & $(0.0731)$ \\
\hline \multirow[t]{2}{*}{ Extrovert } & 0.0383 & 0.1228 & -0.0464 & -0.0442 \\
\hline & $(0.0541)$ & $(0.0769)$ & $(0.0478)$ & $(0.0581)$ \\
\hline \multirow[t]{2}{*}{ Agreeable } & $-0.1317^{* *}$ & -0.1040 & $-0.207^{* * *}$ & $-0.127^{* *}$ \\
\hline & $(0.0542)$ & $(0.0689)$ & $(0.0491)$ & $(0.0557)$ \\
\hline \multirow[t]{2}{*}{ Emotionally stable } & 0.0475 & 0.0633 & -0.0596 & 0.0127 \\
\hline & $(0.0543)$ & $(0.0742)$ & $(0.0450)$ & $(0.0803)$ \\
\hline \multirow[t]{2}{*}{ Constant } & $0.9856^{* * *}$ & $1.8049^{* * *}$ & $3.439^{* * *}$ & $2.873^{* * *}$ \\
\hline & $(0.2984)$ & (0.4399) & $(0.340)$ & $(0.314)$ \\
\hline Observations & 290 & 201 & 552 & 376 \\
\hline R-squared & 0.3837 & 0.3755 & 0.281 & 0.322 \\
\hline
\end{tabular}

Note: Robust standard errors in parentheses. ${ }^{* * *} p<0.01,{ }^{* *} p<0.05,{ }^{*} p<0.1$. All the regressions above control for industry and region.

socioemotional skills as controls, and we find that these significant differences remain. Informal employees are also less likely to receive job training. As such, informal workers may not be gaining the skills that can increase their productivity, a deficit that in itself can perpetuate informality. 
Table 6 Differences in reported job characteristics between formal and informal jobs for Lebanon and Syria

\begin{tabular}{|c|c|c|c|c|c|c|c|}
\hline \multicolumn{4}{|c|}{ Lebanon } & \multicolumn{4}{|l|}{ Syria } \\
\hline Formal & Informal & Difference & $\begin{array}{l}\text { Conditional } \\
\text { difference }^{a}\end{array}$ & Formal & Informal & Difference & $\begin{array}{l}\text { Conditiona } \\
\text { difference }^{a}\end{array}$ \\
\hline (1) & (2) & $(3)=(2)-(1)$ & (4) & (5) & (6) & $(7)=(6)-(5)$ & (8) \\
\hline
\end{tabular}

\begin{tabular}{|c|c|c|c|c|c|c|c|c|}
\hline & (1) & (2) & $(3)=(2)-(1)$ & (4) & (5) & (6) & $(7)=(6)-(5)$ & (8) \\
\hline \multicolumn{9}{|l|}{$\begin{array}{l}\text { Working } \\
\text { conditions/ } \\
\text { Quality of } \\
\text { employment }\end{array}$} \\
\hline $\begin{array}{l}\text { Wants social } \\
\text { security }\end{array}$ & n.a & $67.80 \%$ & n.a & n.a. & n.a. & $65.6 \%$ & n.a. & $\mathrm{n}, \mathrm{a}$. \\
\hline $\begin{array}{l}\text { Looking for } \\
\text { jobs }\end{array}$ & $7.8 \%$ & $19.3 \%$ & $11.50 \%$ & $13.1 \% * * *$ & $20.6 \%$ & $22.7 \%$ & $2.1 \%$ & $3.4 \%$ \\
\hline $\begin{array}{l}\text { Written } \\
\text { contract }\end{array}$ & $64.1 \%$ & $18.4 \%$ & $-45.70 \%$ & $-32.5 \% \%^{* * *}$ & $76.7 \%$ & $26.7 \%$ & $-50.1 \%$ & $-40.8 \% * * *$ \\
\hline $\begin{array}{l}\text { Can ask for } \\
\text { overtime }\end{array}$ & $38.4 \%$ & $27.2 \%$ & $-11.20 \%$ & $-8.2 \% *$ & n.a. & n.a. & n.a. & n.a. \\
\hline $\begin{array}{l}\text { Can refuse } \\
\text { overtime }\end{array}$ & $47.4 \%$ & $33.4 \%$ & $-14.00 \%$ & $-7.5 \% *$ & n.a. & n.a. & n.a. & n.a. \\
\hline $\begin{array}{l}\text { Paid for } \\
\text { overtime }\end{array}$ & $49.3 \%$ & $36.9 \%$ & $-12.40 \%$ & $-8.7 \% * *$ & n.a. & n.a. & n.a. & n.a. \\
\hline $\begin{array}{l}\text { Access to job } \\
\text { training }\end{array}$ & $58.5 \%$ & $29.0 \%$ & $-29.50 \%$ & $-21.7 \% * * *$ & $23.3 \%$ & $14.2 \%$ & $-9.2 \%$ & $-7.5 \%$ ** \\
\hline \multicolumn{9}{|l|}{ Benefits } \\
\hline Annual leave & $85.70 \%$ & $37.30 \%$ & $-48.40 \%$ & $-36.9 \% * * *$ & $92.96 \%$ & $68.2 \%$ & $-24.76 \%$ & $-26.4 \%^{* * *}$ \\
\hline Official leave & $92.30 \%$ & $68.30 \%$ & $-24.00 \%$ & $-20.9 \%$ *** & $96.36 \%$ & $90.85 \%$ & $-5.51 \%$ & $-6.27 \% * * *$ \\
\hline $\begin{array}{l}\text { Emergency } \\
\text { leave }\end{array}$ & $50.70 \%$ & $36.30 \%$ & $-14.40 \%$ & $-11.7 \%$ **** & $54.54 \%$ & $55.72 \%$ & $1.18 \%$ & $5.04 \%$ \\
\hline Maternity leave & $61.20 \%$ & $25.70 \%$ & $-35.50 \%$ & $-23.2 \%$ *** & $4.69 \%$ & $1.26 \%$ & $-3.42 \%$ & $-5.97 \% *$ \\
\hline Sick leave & $87.00 \%$ & $61.40 \%$ & $-25.60 \%$ & $-20.5 \%$ *** & $67.63 \%$ & $58.18 \%$ & $-9.45 \%$ & $-11.8 \%^{* * *}$ \\
\hline $\begin{array}{l}\text { Transport } \\
\text { allowance }\end{array}$ & $73.80 \%$ & $26.40 \%$ & $-47.40 \%$ & $-36.6 \%$ & $78.47 \%$ & $55.4 \%$ & $-23.07 \%$ & $-7.5 \%$ \\
\hline $\begin{array}{l}\text { Family } \\
\text { allowance }\end{array}$ & $62.80 \%$ & $9.87 \%$ & $-52.93 \%$ & $-47.3 \%$ & $18.61 \%$ & $2.2 \%$ & $-16.39 \%$ & $-4.41 \%^{* * *}$ \\
\hline
\end{tabular}

Note: n.a. = not applicable.

${ }^{a}$ Conditional differences present means conditional on age, age squared, gender, years of education, and firm size.

Interestingly, the difference between formal and informal workers in average hours worked per week is small and not statistically significant in Lebanon ${ }^{18}$. This is not the case for Syria, where informal workers worked an average of 2.1 hours more per week than formal workers and this difference is statistically significant. Moreover, when access to annual or other types of leave is accounted for, informal workers end up working significantly more per year than formal workers in both countries.

Table 6 also looks at the differences between formal and informal workers in terms of access to benefits. For instance, in Lebanon, 85 percent of formal workers benefit from annual leave, whereas only 37 percent of informal workers receive annual leave. In general, informal workers in Lebanon and Syria are significantly less likely to have access to benefits such as family, sick, or maternity leaves. Furthermore, in Lebanon, only 26 percent of informal workers receive any transport allowance, while over 70 percent of formal employees get such an allowance. These discrepancies between 
formal and informal workers in access to benefits hold true even when we control for education, gender, age, and firm size.

Moreover, in Lebanon, informal workers are more likely than formal workers to want to change jobs or to be searching for new employment, even when age, education, and other characteristics are taken into account. We thus explore this difference in detail by including a richer set of controls (e.g., industry, region, and cognitive and socioemotional ability) in probit regressions (see Table 7). Even controlling for this rich set of controls, informal employees are 21 percentage points more likely than formal ones to want to change jobs. This suggests that informal employees are more likely to be dissatisfied with their jobs and stuck in employment that they find less than optimal. In Syria, where workers were asked directly about how satisfied they were with their jobs, informal workers are less likely than formal ones to be satisfied when age, education, and other characteristics are taken into account. However, although the coefficient is positive, it is not significant (see Table 7) ${ }^{19,20}$.

The evidence on the quality of jobs in the formal and informal sectors suggests the existence of segmentation in the labor market, especially in Lebanon. In the Middle East and North Africa, informal work is generally associated with worse job conditions, and the wage gaps between formal and informal workers indicate that informal workers do not seem to be compensated for these differences in job conditions. Indeed, the wage analysis in the section above suggests that informal workers have lower wages than formal workers with similar personal characteristics. In Lebanon, we find evidence that informal workers are significantly more likely to want to change jobs. However, in economies such as those in the Middle East and North Africa, where high-quality job growth is low (Gatti et al. 2012), lower pay and worse conditions in the informal sector might be seen by workers as a last-resort option, especially for workers who cannot wait until a formal or public job becomes available.

\subsection{Self-employment in Lebanon}

There is evidence in the literature that informality for the self-employed is often a choice, whereas informal wage employment is not (Maloney 2004; Arias and Khamis 2009). We investigate this hypothesis in Lebanon. The evidence in this paper-showing a significant wage gap between informal and formal employees as well as significant job-quality differences between formal work and informal wage work-indicates that informal wage work is likely not a choice. On the other hand, there is a statistically significant (26 percent) wage premium between self-employment and informal employment when the relevant controls are in the equation (see Table 8). This evidence suggests that self-employment, while informal, is more likely to be an individual's choice when compared with formal employment. Even though the self-employed lack the benefits of social insurance, this lack might be implicitly offset by their desire for autonomy (Arias and Khamis 2009).

\section{Conclusion and policy implications}

This paper examines earnings differentials between formal and informal jobs and the presence of other labor market divides between formal and informal labor markets in Lebanon and Syria. It uses data from matched employer-employee surveys collected in Lebanon and Syria. The analysis controls for cognitive and socioemotional ability when 
Table 7 Probit regression for wanting to change jobs (Lebanon) and job satisfaction (Syria) (marginal effects reported)

\begin{tabular}{|c|c|c|c|c|}
\hline \multirow[t]{2}{*}{ Dependent variable: } & \multicolumn{2}{|c|}{ Lebanon - want to change jobs } & \multicolumn{2}{|c|}{ Syria - job satisfaction } \\
\hline & $(1)$ & $(2)$ & $(3)$ & (4) \\
\hline \multirow[t]{2}{*}{ Formal } & $-0.2140^{* * *}$ & $-0.2099 * * *$ & 0.0173 & 0.0116 \\
\hline & $(0.0535)$ & $(0.0559)$ & $(0.0295)$ & $(0.0281)$ \\
\hline \multirow[t]{2}{*}{ Female } & -0.0086 & -0.0034 & $0.0476^{*}$ & $0.0534^{* *}$ \\
\hline & $(0.0488)$ & $(0.0498)$ & $(0.0280)$ & $(0.0271)$ \\
\hline \multirow[t]{2}{*}{ Years of education } & 0.0016 & 0.0010 & 0.00245 & 0.00213 \\
\hline & $(0.0049)$ & $(0.0053)$ & $(0.00223)$ & $(0.00243)$ \\
\hline \multirow[t]{2}{*}{ Age } & $0.0258^{*}$ & $0.0276^{*}$ & -0.00190 & -0.00124 \\
\hline & $(0.0140)$ & $(0.0143)$ & $(0.00840)$ & $(0.00878)$ \\
\hline \multirow[t]{2}{*}{$\mathrm{Age}^{2}$} & $-0.0004^{* *}$ & $-0.0004^{* *}$ & $7.10 \mathrm{e}-05$ & $6.79 e-05$ \\
\hline & $(0.0002)$ & $(0.0002)$ & $(0.000116)$ & $(0.000123)$ \\
\hline \multirow[t]{2}{*}{ Firm size < (base 10-49) } & -0.0368 & -0.0511 & -0.00745 & -0.00563 \\
\hline & $(0.0665)$ & $(0.0688)$ & $(0.0479)$ & $(0.0501)$ \\
\hline \multirow[t]{2}{*}{ Firm size 5-9 } & -0.0067 & -0.0151 & 0.0551 & $0.0605^{*}$ \\
\hline & $(0.0778)$ & $(0.0783)$ & $(0.0340)$ & $(0.0314)$ \\
\hline \multirow[t]{2}{*}{ Firm size $>50$} & 0.0751 & 0.0505 & -0.0130 & -0.0173 \\
\hline & $(0.0574)$ & $(0.0587)$ & $(0.0367)$ & $(0.0373)$ \\
\hline \multirow[t]{2}{*}{ Cognitive score quintile 2} & & -0.0412 & & 0.0117 \\
\hline & & $(0.0666)$ & & $(0.0370)$ \\
\hline \multirow[t]{2}{*}{ Cognitive score quintile 3} & & 0.0606 & & 0.00304 \\
\hline & & $(0.0735)$ & & $(0.0306)$ \\
\hline \multirow[t]{2}{*}{ Cognitive score quintile 4} & & 0.0993 & & -0.0285 \\
\hline & & $(0.0812)$ & & $(0.0415)$ \\
\hline \multirow[t]{2}{*}{ Cognitive score quintile 5} & & 0.1219 & & 0.0417 \\
\hline & & $(0.0797)$ & & $(0.0409)$ \\
\hline \multirow[t]{2}{*}{ Open to experience } & & $0.0797^{*}$ & & -0.0294 \\
\hline & & $(0.0466)$ & & $(0.0286)$ \\
\hline \multirow[t]{2}{*}{ Conscientious } & & $-0.0975^{*}$ & & 0.00384 \\
\hline & & $(0.0498)$ & & $(0.0337)$ \\
\hline \multirow[t]{2}{*}{ Extravert } & & 0.0012 & & $-0.0584^{* *}$ \\
\hline & & $(0.0484)$ & & $(0.0252)$ \\
\hline \multirow[t]{2}{*}{ Agreeable } & & 0.0193 & & -0.0414 \\
\hline & & $(0.0492)$ & & $(0.0300)$ \\
\hline \multirow[t]{4}{*}{ Emotionally stable } & & $-0.1014^{* *}$ & & $0.0632^{* *}$ \\
\hline & & $(0.0466)$ & & $(0.0299)$ \\
\hline & 503 & 491 & & 928 \\
\hline & 0.0737 & 0.101 & & 0.0430 \\
\hline
\end{tabular}

Note: Robust standard errors in parentheses. ${ }^{* *} p<0.01,{ }^{* *} p<0.05,{ }^{*} p<0.1$. All the regressions above control for industry and region.

estimating the wage premium associated with formal employment. It finds that, even with a rich set of controls for workers and firms' characteristics, the formality premium persists at 22 percent and 12 percent in Lebanon and Syria, respectively. 
Table 8 Wage premium regressions for Lebanon self-employed vs. informal employees

\begin{tabular}{|c|c|c|}
\hline Dependent variable log earnings per hour & $(1)$ & $(2)$ \\
\hline \multirow[t]{2}{*}{ Self-employed } & $0.2674^{* * *}$ & $0.2597^{* * *}$ \\
\hline & $(0.0470)$ & $(0.0453)$ \\
\hline \multirow[t]{2}{*}{ Female } & $-0.1473^{* * *}$ & $-0.1350^{* * *}$ \\
\hline & $(0.0517)$ & $(0.0504)$ \\
\hline \multirow[t]{2}{*}{ Years of education } & $0.0199^{* * *}$ & $0.0163^{* * *}$ \\
\hline & $(0.0042)$ & $(0.0044)$ \\
\hline \multirow[t]{2}{*}{ Age } & $0.0239^{* * *}$ & $0.0243^{* * *}$ \\
\hline & $(0.0081)$ & $(0.0084)$ \\
\hline \multirow[t]{2}{*}{$\mathrm{Age}^{2}$} & $-0.0003^{* * *}$ & $-0.0003^{* *}$ \\
\hline & $(0.0001)$ & $(0.0001)$ \\
\hline \multirow[t]{2}{*}{ Cognitive score quintile 2} & & 0.0667 \\
\hline & & $(0.0546)$ \\
\hline \multirow[t]{2}{*}{ Cognitive score quintile 3} & & $0.1227^{* *}$ \\
\hline & & $(0.0583)$ \\
\hline \multirow[t]{2}{*}{ Cognitive score quintile 4} & & $0.1444^{* *}$ \\
\hline & & $(0.0635)$ \\
\hline \multirow[t]{2}{*}{ Cognitive score quintile 5} & & 0.1046 \\
\hline & & $(0.0663)$ \\
\hline \multirow[t]{2}{*}{ Open to experience } & & 0.0357 \\
\hline & & $(0.0404)$ \\
\hline \multirow[t]{2}{*}{ Conscientious } & & -0.0585 \\
\hline & & $(0.0388)$ \\
\hline \multirow[t]{2}{*}{ Extravert } & & 0.0525 \\
\hline & & $(0.0410)$ \\
\hline \multirow[t]{2}{*}{ Agreeable } & & $-0.1340^{* * *}$ \\
\hline & & $(0.0405)$ \\
\hline \multirow[t]{2}{*}{ Emotionally stable } & & $0.1090^{* * *}$ \\
\hline & & $(0.0416)$ \\
\hline \multirow[t]{2}{*}{ Constant } & $0.8893^{* * *}$ & $0.8492^{* * *}$ \\
\hline & (0.1913) & (0.1943) \\
\hline Observations & 759 & 734 \\
\hline R-squared & 0.2101 & 0.2543 \\
\hline
\end{tabular}

Note: Robust standard errors in parentheses. ${ }^{* *} \mathrm{p}<0.01,{ }^{* *} \mathrm{p}<0.05,{ }^{*} \mathrm{p}<0.1$. Regression (2) includes industry and region dummies.

Notably, we also find that most measures of job quality-including choosing when to work overtime, being paid for overtime work, and receiving job training-point to worse working conditions among informal jobs. At the same time, informal employees are significantly less likely to have job benefits. These findings indicate that the wage gap, or informality penalty, is not offset by better working conditions or more generous benefits. Overall, they suggest that informality among waged employees is not the result of individual choice but is more likely due to exclusion from the formal sectorparticularly in Lebanon, where the evidence indicates that informal workers are significantly more likely to want to change jobs. 
These findings suggest that governments in both countries may want to be proactive in removing existing barriers to the creation of high-quality, formal jobs. Evidence from Brazil (Bruhn and McKenzie 2013) and Mexico (Bruhn 2011) shows that introducing business-friendly reforms (e.g., simplified tax systems and one-stop shops for business registration) or more frequent tax and labor inspections can produce small improvements. Regarding the Middle East and North Africa, Gatti et al. (2012) argue that a broad reform agenda will be needed to foster sustainable, high-value-added job growth and reduce informality. Such an agenda will include fostering competition, moving toward labor regulations that promote labor mobility and support during transitions, realigning incentives in the public sector, reforming existing social insurance systems, and improving workers' productivity by building better skills.

\section{Endnotes}

${ }^{1}$ The Schneider Shadow Economy Index estimates the share of overall GDP that is not declared to tax and regulatory authorities. It combines the multiple-indicator, multiple-cause method, the physical input method, and the excess currency-demand approach to estimate informality's share of GDP (Schneider 2004).

${ }^{2}$ See Maloney (1999) and Bosch and Maloney (2010) for evidence for Mexico and Brazil, and Perry et al. (2007) for an extensive discussion focused on countries in Latin America and the Caribbean.

${ }^{3}$ The NSSF in Lebanon provides employees with health insurance coverage, end of service pension, family allowances, and insurance for work-related accidents.

${ }^{4}$ Self-employed individuals are not registered in NSSF and are also considered informal.

${ }^{5}$ Data from the 2009 Syrian Labor Force Survey.

${ }^{6}$ Data from the General Establishment for Social Insurance of Syria for 2009.

${ }^{7}$ Public sector employees were excluded from the survey.

${ }^{8}$ For a summary of Enterprise Survey data for Syria, see http://www.enterprisesurveys.org/ Data/ExploreEconomies/2009/syria.

${ }^{9}$ The analysis was also conducted using the average rankings (1 through 7$)$, yet this did not improve the predictive power of the model and further complicated the interpretation of the results.

${ }^{10}$ Results for Syria using a linear probability model or FE logit are qualitatively similar and available from the authors upon request.

${ }^{11}$ The industries here are grouped into agriculture, manufacturing, and services.

${ }^{12}$ The only exceptions in Syria are individuals above 54 years of age or located in Hama.

${ }^{13}$ Descriptive statistics for variables used in the regressions for Lebanon and Syria are available upon request.

${ }^{14}$ Results in Syria using a model with firm fixed effects are qualitatively similar and available from the authors upon request.

${ }^{15}$ Results are similar when firm fixed effects are taken into account.

${ }^{16}$ The separate regressions also indicate gender-related wage discrimination in both sectors in Syria. Further, the regressions for Lebanon show that age is an important factor in determining wages in the formal sector but not the informal one.

${ }^{17}$ The data with respect to overtime are available only for Lebanon. 
${ }^{18}$ In Lebanon, informal employees work, on average, 48.4 hours (or 5.78 days) per week compared with 46.96 hours (or 5.66 days) per week for formal employees. In Syria, informal employees work an average of 50.8 hours and 5.96 days compared with 48.73 hours and 5.83 days for formal employees. A $t$-test reported a p-value of 0.16 in Lebanon and of 0.0036 in Syria.

${ }^{19}$ One explanation for this is the role that public sector employment plays in the Syrian labor market. Public employment is considered desirable, and the overall job satisfaction of both formal and informal private employees may be tied to the attractiveness of public sector employment. In Syria, according to the General Organization for Social Insurance, 69 percent of formal sector jobs are in the public sector, which is not the case in Lebanon.

${ }^{20}$ Information on overall job satisfaction was not collected in Lebanon.

\section{Competing interests}

The IZA Journal of Labor Policy is committed to the IZA Guiding Principles of Research Integrity. The authors declare that they have observed these principles.

\section{Acknowledgements}

We would like to thank the editor and referees for their excellent comments and suggestions. In addition, we would like to acknowledge Andras Bodor, Diego Angel-Urdinola, May Wazzan, Matteo Morgandi, Haneen Sayed, and David Robalino for their input and contributions in the early stages of writing this paper. The views expressed in this paper are those of the authors and should not be attributed to the institutions they are affiliated with. The research for this paper began in 2010, prior to the Syrian conflict that started in early 2011 and continued as of November 2013. The data reflect prior circumstances, and the policy recommendations are considered apart from these events. Responsible editor: David Neumark

Received: 1 November 2012 Accepted: 14 November 2013

Published: 23 Dec 2013

\section{References}

Angel-Urdinola D, Reis JG, Quijada C (2009) Informality in Turkey: Size, Trends, Determinants and Consequences. Unpublished manuscript, World Bank, Washington, DC

Arias O, Khamis M (2008) Comparative Advantage, Segmentation and Informal Earnings: A Marginal Treatment Effects Approach. In: IZA Discussion Paper 391. Institute for the Study of Labor (IZA), Bonn

Arias O, Khamis M (2009) Comparative Advantage, Segmentation and Informal Earnings: A Marginal Treatment Effects Approach. IZA Discussion Papers 391

Borghans L, Duckworth AL, Heckman JJ, ter Weel B (2008) The Economics and Psychology of Personality Traits. Journal of Human Resources 43:972-1059

Bosch M, Maloney W (2010) Comparative Analysis of Labor Market Dynamics Using Markov Processes: An Application to Informality. Labour Economics 17:621-631

Bowles S, Gintis H, Osborne M (2001) The Determinants of Earnings: A Behavioral Approach. Journal of Economic Literature 39(4):1137-1176

Bruhn M (2011) Reforming Business Taxes: What Is the Effect on Private Sector Development? In: Viewpoint: Public Policy for the Private Sector, Note No. 330. World Bank, Washington, DC. http://siteresources.worldbank.org/ EXTFINANCIALSECTOR/Resources/282884-1303327122200/VP330-Reforming-Business-Taxes.pdf

Bruhn M, McKenzie D (2013) Entry Regulation and Formalization of Microenterprises in Developing Countries. In: Policy Research Working Paper 6507. World Bank, Washington, DC

De Soto H (1989) The Other Path: The Invisible Revolution in the Third World. HarperCollins, New York

Fields GS (2005) A Guide to Multisector Labor Market Models. In: Paper prepared for the. World Bank Labor Market Conference, Washington, DC. November 18-19 2004. http://digitalcommons.ilr.cornell.edu/workingpapers/86/

Gasparini L, Tornarolli L (2009) Labor Informality in Latin America and the Caribbean: Patterns and Trends from Household Survey Microdata. Revista Desarrollo Y Sociedad 63(1):13-80

Gatti R, Angel-Urdinola D, Silva J, Bodor A (2012) Striving for Better Jobs: The Challenge of Informality in the Middle East and North Africa. Directions in Development Series. World Bank, Washington, DC

Goldberg LR (1993) The Structure of Phenotypic Personality Traits. American Psychologist 48(1):26-34

Green DA, Riddell WC (2003) Literacy and Earnings: An Investigation of the Interaction of Cognitive and Unobserved Skills in Earnings Generation. Labour Economics 10:165-184

Griliches Z (1977) Estimating the Returns to Schooling: Some Econometric Problems. Econometrica 42:1-22

Gunther I, Launov A (2011) Informal Employment in Developing Countries: Opportunity of Last Resort? Journal of Development Economics 97:88-98

Hansen KT, Heckman JJ, Mullen KJ (2004) The Effect of Schooling and Ability on Achievement Test Scores. Journal of Econometrics 121(1-2):39-98

Heckman JJ, Rubinstein Y (2001) The Importance of Noncognitive Skills: Lessons from the GED Testing Program. Am Econ Rev 91(2):145-149 
Heckman JJ, Stixrud J, Urzua S (2006) The Effects of Cognitive and Noncognitive Abilities on Labor Market Outcomes and Social Behavior. In: Working Paper 12006. National Bureau of Economic Research, Cambridge, MA

Jensen AR (1998) The g Factor: The Science of Mental Ability. Praeger, Westport, CT

John OP, Srivastava S (1999) The Big Five Trait Taxonomy: History, Measurement, and Theoretical Perspectives. In: Pervin L, John OP (ed) Handbook of Personality: Theory and Research, 2nd edition. Guilford, New York, pp 102-138

Kasparian C (2009) L'Emigration des jeunes Libanais et leurs projets d'avenir. Presse de l'Universite Saint Joseph, Beirut, Lebanon

Loayza N, Wada T (2010) Informal Labor in the Middle East and North Africa: Basic Measures and Determinants. Unpublished manuscript, World Bank, Washington, DC

Maloney W (1999) Does Informality Imply Segmentation in Urban Labor Markets? Evidence from Sectoral Transitions in Mexico. World Bank Economic Review 13(2):275-302

Maloney W (2004) Informality Revisited. World Dev 32(7):1159-1178

Marcoullier D, Ruiz de Casilla V, Woodrugg C (1997) Formal Measure of the Informal-Sector Wage Gap in Mexico, El Salvador, and Peru. Economic Development and Cultural Change 45(2):367-392

Nguyen HC, Nordman CJ, Roubaud F (2013) Who Suffers the Penalty? A Panel Data Analysis of Earnings Gaps in Vietnam. In: IZA Discussion Paper 7149. Institute for the Study of Labor (IZA), Bonn

Paulson AL, Townsend RM (2005) Financial Constraints and Entrepreneurship: Evidence from the Thai Financial Crisis. Economic Perspectives 29(3):34-48

Paunonen SV (2003) Big Five Factors of Personality and Replicated Predictions of Behavior. J Pers Soc Psychol 84(2):411-422

Perry G, Maloney W, Arias O, Fajnzylber P, Mason A, Saavedra-Chanduvi J (2007) Informality: Exit and Exclusion: Building Effective and Legitimate Institutions. Latin American and Caribbean Studies. World Bank, Washington DC

Raven J (1989) The Raven Progressive Matrices: A Review of National Norming Studies and Ethnic and Socioeconomic Variation within the United States. Journal of Educational Measurement 26(1):1-16

Robalino DA (2005) Pensions in the Middle East and North Africa: Time for a Change. Orientations in Development Series. World Bank, Washington DC

Robalino D, Pierre G, Elzir A (2012) Understanding the Lebanese Labor Market. In: In Lebanon, Good Jobs Needed: The Role of Macro, Investment, Education, Labor and Social Protection Policies (MILES). Washington, DC, World Bank, pp 11-34. Forthcoming

Schneider F (2004) The Size of the Shadow Economies of 145 Countries All over the World: First Results over the Period 1999 to 2003. In: IZA Discussion Paper 1431. Institute for the Study of Labor (IZA), Bonn

10.1186/2193-9004-2-18

Cite this article as: Alloush et al: Informality and exclusion: evidence from matched employer-employee data for Lebanon and Syria. IZA Journal of Labor Policy 2013, 2:18

\section{Submit your manuscript to a SpringerOpen ${ }^{\circ}$ journal and benefit from:}

- Convenient online submission

- Rigorous peer review

- Immediate publication on acceptance

- Open access: articles freely available online

- High visibility within the field

- Retaining the copyright to your article

Submit your next manuscript at $\gg$ springeropen.com 